\title{
Research Paper \\ Examination of the Trend of Changes in Rural Areas of Dalfard Rural District With Emphasis on the Role of Jiroft City
}

\author{
Ali Hajinejad', *Aboozar Paidar², Habibullah Bayad ${ }^{3}$
}

1. Associate Professor, Depatrment of Geography, Faculty of Literature and Humanities, University of Guilan, Rasht, Iran.

2. Assistant Professor, Departmant of Human Geography, Faculty of Geography and Environmental Planning, University of Sistan and Baluchestan, Zahedan, Iran .

3. MA, Departmant of Human Geography, Faculty of Geography and Environmental Planning, University of Sistan and Baluchestan, Zahedan, Iran.

Citation: Hajinejad, A., Paidar, A., \& Bayad, H. (2016). Examination of the Trend of Changes in Rural Areas of Dalfard Rural District With Emphasis on the Role of Jiroft City. Journal of Rural Research, 7(2), 344-361.

\section{doi:}

Received: 21 Dec. 2015

Accepted: 24 Feb. 2016

Key words:

Sustainable rural

development, Spa-

tial reforms, Struc-

tural and functional

changes, Model

WASPAS, Dalfard

rural district

\section{A B STRACT}

This descriptive and analytical study analyzes the functional and spatial changes in the rural areas of Dehestan Dlfard. Qualitative and quantitative methods, including observations and questionnaires, were used for collecting the data. Descriptive statistics and data analysis methods and techniques of assessment of the cumulative weight (WASPAS) were also used for analyzing the data. The study population included the residents, local authorities, and village councils and Dehyaris of the study site. The sample size was determined using the formula 386 Cochran with quota was distributed according to the proportion of the population between villages. The results of the analysis of institutional statistics, interviews, and observation revealed the tangible and concrete changes in the field of residential, economic, and rural population. The t-test results indicated significant positive and constructive changes in recent years, especially in the physical, cultural, and socio-economic aspects. The results WASPAS model also showed the villages such as Mazar-e-Dara and Rzshyryn had the highest rate of change. Based on the findings, it can be confirmed and concluded that the functional-structural changes in most of the Dalfard villages generated a dynamic process.

\section{Extended Abstract}

\section{Introduction}

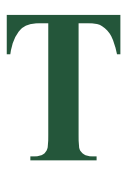

he aim of this study is to examine the functional- structural changes in the villages of Dalfard Rural District with an emphasis on the role of Jiroft city. The Dalfard Rural District is located at 30 to $45 \mathrm{~km}$ north-west of Jiroft city and has been confronted with several changes in recent years. There are 22 villages and 44 farms in this district. In line with the objective, the following research question is posed: What structural and functional changes have occurred in the villages of Dalfard?

\section{Methodology}

The type of research is descriptive-analytic, and the study used qualitative and quantitative methods to col- 
lect and analyze data. Data collection methods include field and library with tools as organization and questioner. For the analysis of data, descriptive statistics (calculated mean difference) and mathematical techniques (techniques assessment of the cumulative weight) were used. The population included residents, local authorities, and village councils and Dalfard Rural municipality.

The sample size was determined using Cochran's formula: 386 villages in 10 districts with a population of quota per share was distributed. The following changes were evaluated: changes in housing, communication paths pattern changes, changes of land use, change the pattern of agricultural production, changes in the pattern of agricultural land, tourism changes, changes in trade and commerce, economic changes, and social changes in terms of the rate of hybridization and structure Sunnis. Ranking villages in 10 districts was done by the WASPAS model and based on 5 criteria (the social reform, cultural reform, economic reform, physical rebuild, environmental rebuild). In order to test the hypothesis of "functional structural changes in rural areas of the district Dalfard has a creative and dynamic process", the analysis was conducted on various aspects of the reforms and changes in different rural life dimensions.

\section{Results}

Field findings showed that changing lifestyles and living patterns, traditional villages of the district of residence and work has led to new ways. The growing rural population, advances in technology, and the replacement of capital rather than labor, the new body rebuild villages, farms and agricultural reforms, changes in immigration patterns, and the spread of second homes, can be seen as manifestations of change and reform in the Dalfard region. The findings of this study confirm the findings of previous researchers because the dynamics of change in rural areas focus on different aspects.

The results of the analysis of institutional statistics, interviews, and observation shows the tangible and concrete changes in the field of residential, economic and rural population Dalfard tangible. T-test results indicated significant changes in recent years, especially in the physical, cultural, and socio-economic aspects, and these changes are positive and constructive. The results also showed WASPAS model villages such as Mazar-e-Dara and Rzshyryn that have closer communication path and a shorter distance to the city of Jiroft have the highest rate of change.

\section{Discussion}

The reform changes in Dalfard features may have resulted from urban functions in these villages. These features improve the livelihoods and lives of people in rural areas Dalfard shows that the urban functions are realized without extensive experience in municipal Dalfard, and the changes are organic and creative. Based on the findings and results, it can be confirmed and concluded that the research hypothesis involves functional structural changes in rural areas of Dalfard villages. In order to continue the dynamic aspects, the villages of Dalfard Zayndgy changes need to be implemented the following strategies:

1) Urban functions should be provided for rural Dalfard without damage to the nature of rural areas change. The physical features of the village are compatible with the environment. With an emphasis on local materials and repair communication paths and development of the rural market, the purchase and sale of land and pressure groups also monitor the performance of the manufacturer (led changes to the spatial-physical stability),

2) To achieve sustainable rural economy, further strengthening of the sector such as tourism trade and market-oriented horticulture, development of rental cottages, gardens and restaurants Talarbagh development, ecotourism development, particularly forests luggage, Mountain, Waterfall Dalfard, and creating pools cold water for a swim in the river Dalfard should be emphasized (directed changes to the economic stability),

3) Measures such as the implementation of modern irrigation systems, tree planting projects in partnership with local operators, creating parks and protecting existing forests (directed changes towards environmental sustainability),

4) Prevent the sale of excess land in order to prevent the occurrence of hybridization and creation of ethnic and cultural conflicts. The behavior of tourists and residents in the villages should be monitored in order to prevent social problems, and programs to preserve links and the convergence of the villagers as social capital (directed changes to the social stability) should be developed.

\section{Conclusion}

Based on the findings, the hypothesis was confirmed and it was concluded that functional-structural changes in villages of Dalfard generated a dynamic process on the most dimensions. 


\title{
تحليل روند تغييرات و تحولات روستاهاى دهستان دلفارد با تأكيد بر نقش شهر جيرفت
}

\author{
على حاجىنزاد'، "ابوذر بايدارّ'، حبيبالله بياد" \\ ا - داتشيار، كروه جغرافيا، دانشكده ادبيات و علوم انساني، دانشكاه كيلان، رشت، ايران.

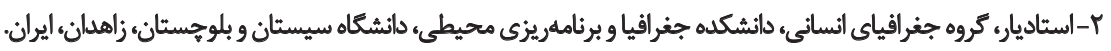

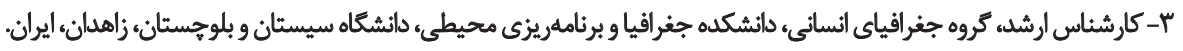

\begin{abstract}
حكبن

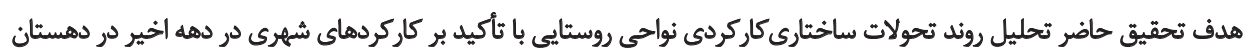

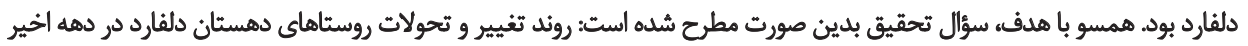

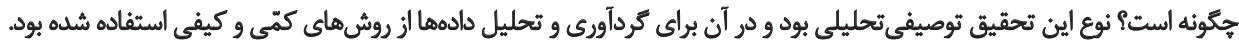

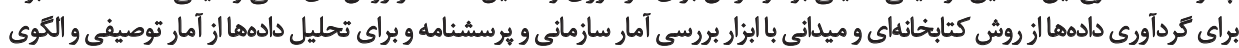

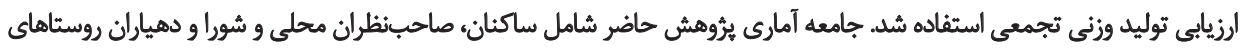

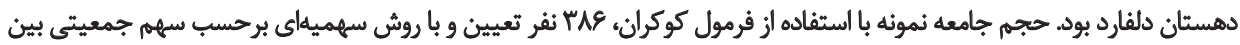

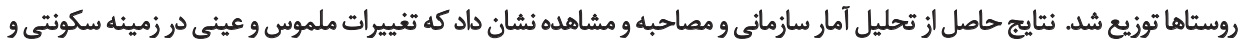

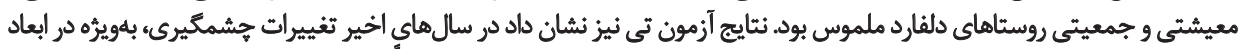

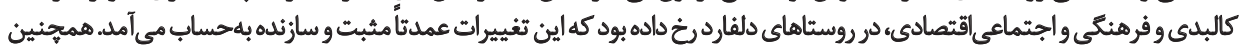

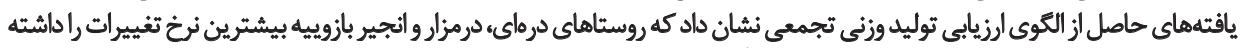

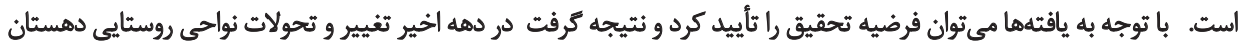

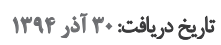

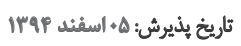

در قالب نقش لازمينهساز و تسهيل

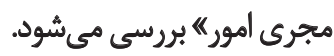

در طول زمان سكوئتكاههاى روستاييى بهعنوان فضايى جغرافيايى،

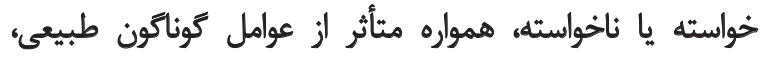
اجتماعى فرهنكى، اقتصادى و سياسى در حال تغيير و تحول و تكامل

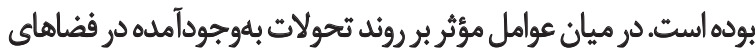

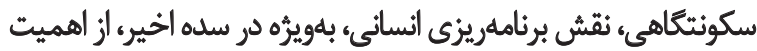

بيشترى برخوردار بوده است (Rahmani Fazli \& Parishan, 2009).

رواج شيوهایى نوين معيشت و زندكى در مناطق روستايى، جهره

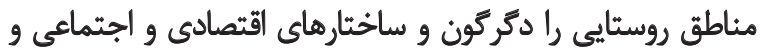

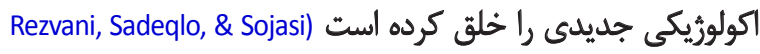

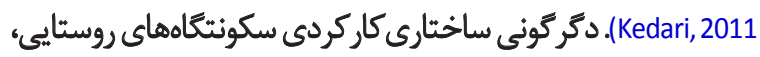

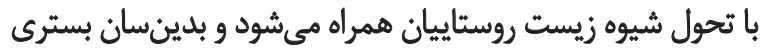

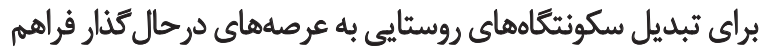

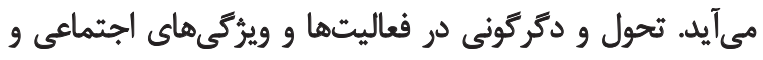

dosto.)

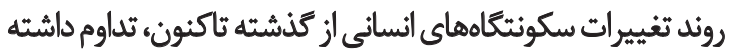

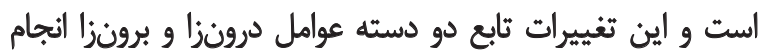

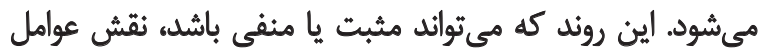
مختلف درونى مائند عوامل طبيعى و اجتماعى اقتئصادى و و عوامل

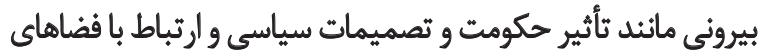
شهرى و روستايى ديگر را بر تحولات نواحى روستائي نشان مي تصدهد. در عرصههاى مختلف مكانيىفضايى، عوامل گوناكونى به ساختار

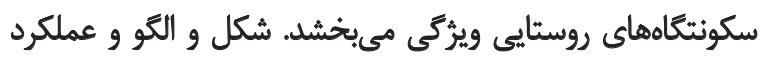

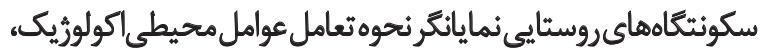
مناسبات اجتماعىاقتصادى، مجموعه سياست كذارىها و روندهاي مكانىفضايي در بستر زمان است (Saidi \& Ahmadi, 2011). ثأثيرات

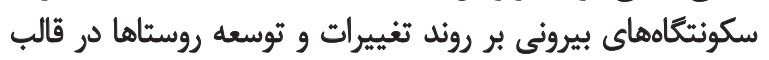

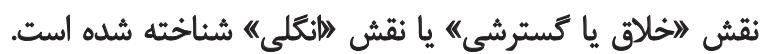

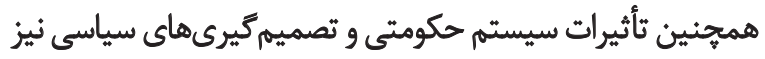


سياست كذارىها در روند تغييرات فضاهاى روستايى و نقش رونش

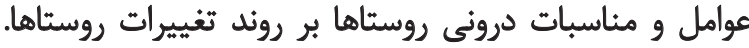

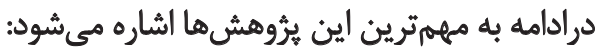

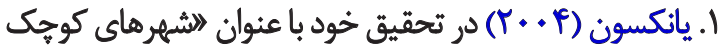

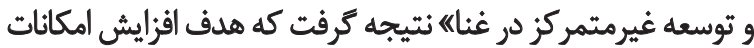

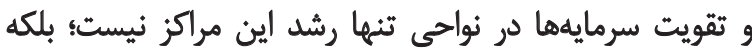

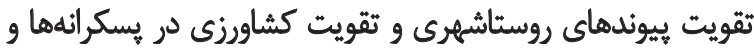
بلوجودآوردن فرصتهاى اشتغال براى كشاورزان است.

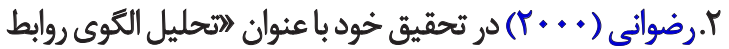

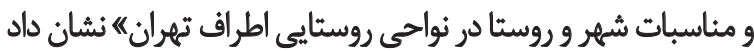

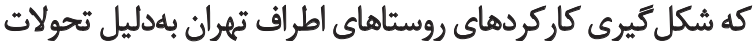

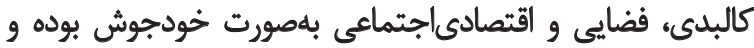

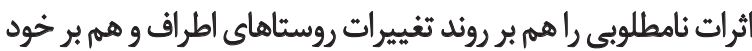
شهر تهران برجاى كذاشته است.

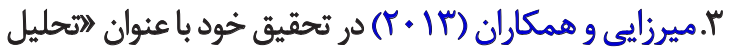

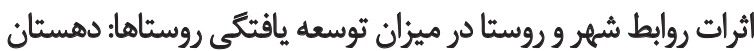

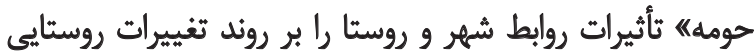

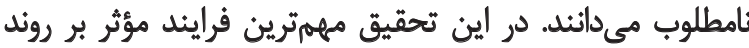

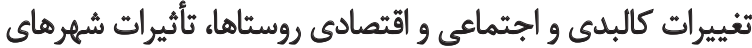

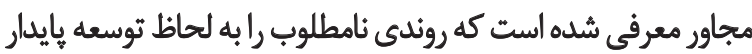

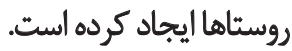

f. علىزاده و همكاران (rا. (T) در تحقيق خود با عنوان

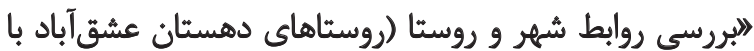

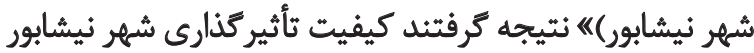

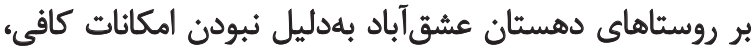

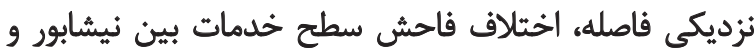

$$
\text { دهستان عشق آباد و... نامطلوب است فاحث سطع }
$$

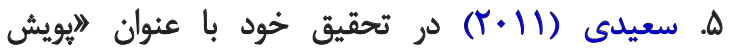

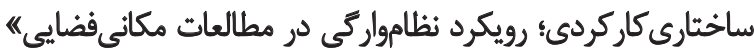

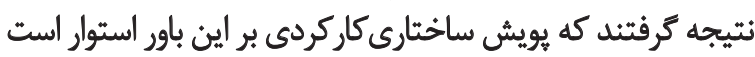

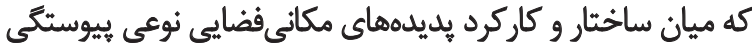

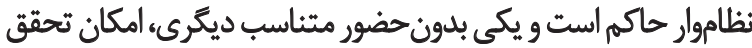

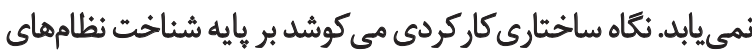

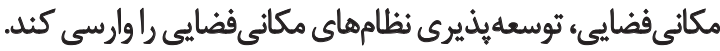

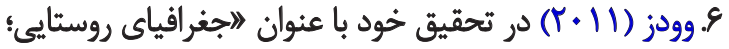

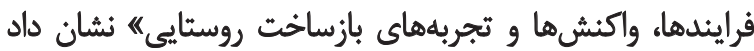

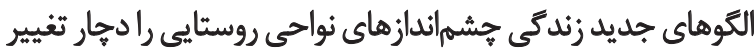

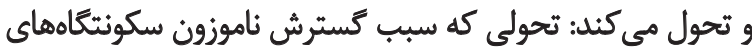

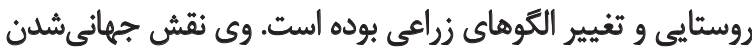

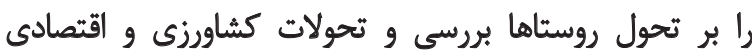

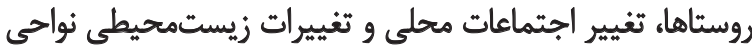

اقتصادى سكونتمًاهاى روستايى بهعنوان بديدهاي يويا، از طريق

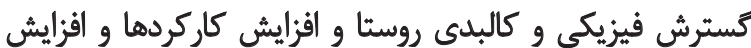

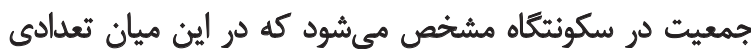

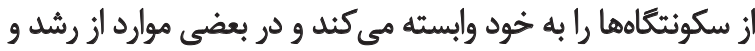

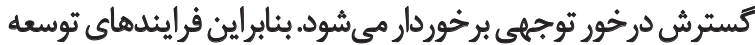

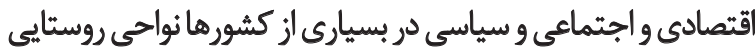

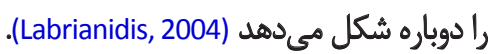

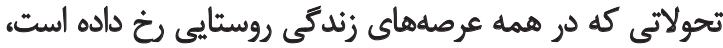

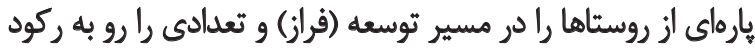

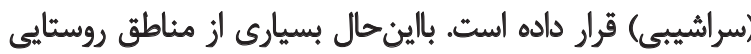

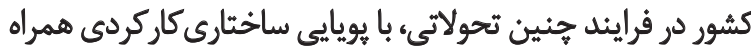

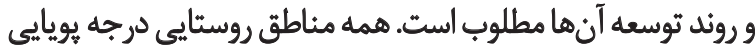

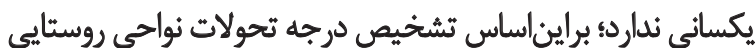

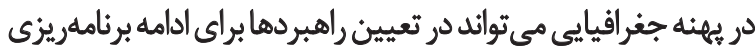
و مديريت توسعه نواحى روستايى مؤثر باشد (Wirth, 1938).

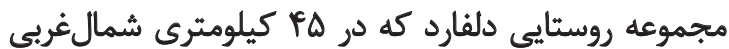

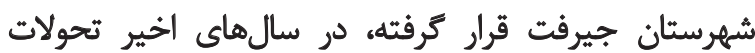

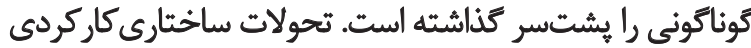

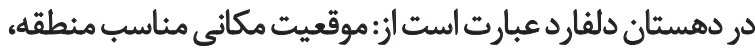

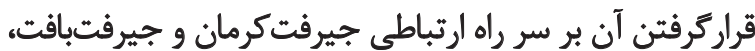

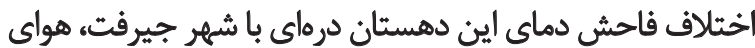

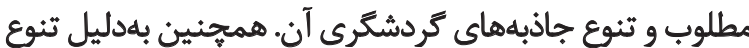

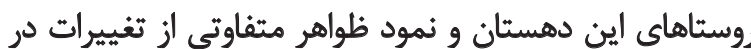

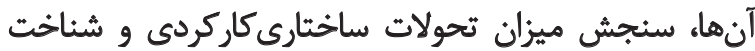

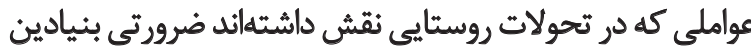

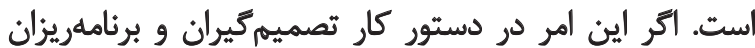

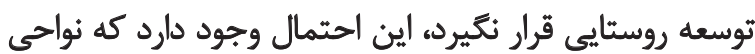

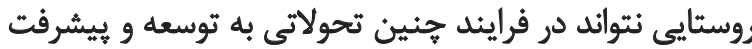

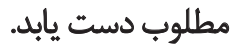
با توجه به اينكه امروزه مأموريت جغرافى انان، بهعنوان ناظران و مشاوران واقعى توسعه مكانى اين است كه كيفيت و جهنت

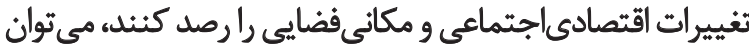

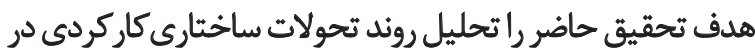

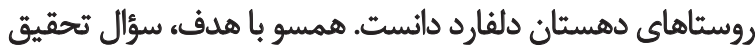
بدينصورت مطرح شده است: روند تغيير و تحولات روستان رداهان

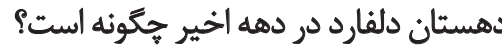

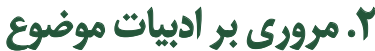

$$
\text { يبينه تحقيق }
$$

در زمينه تحولات ساختارى كاركردى روستاها يُرؤهشهاي

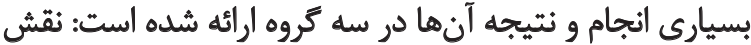

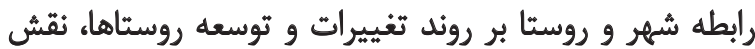


شهرى در مقياس منطقهايى و محلى استوار است.

رواج راهبردهاي توسعه بازارمحور و تأكيد بر توليدهائ إنائي

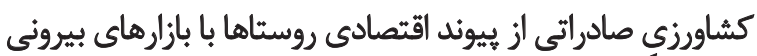

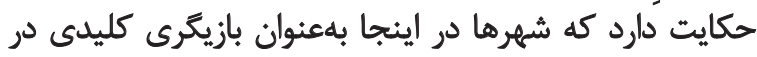

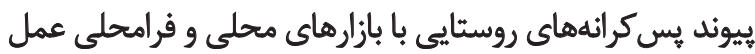

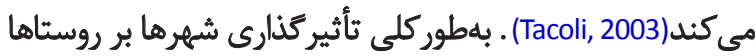

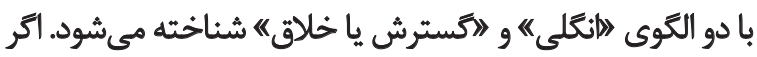

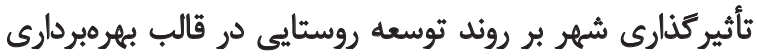

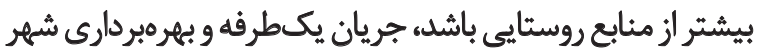

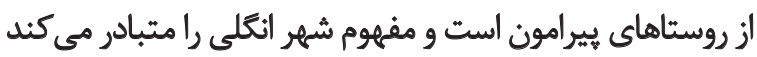

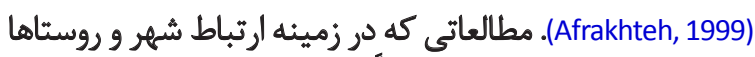

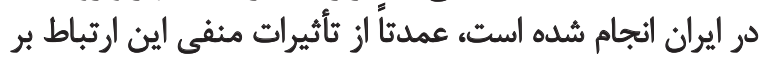

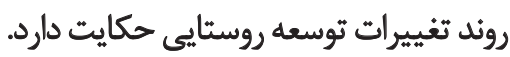

در كشور ايران كه اقتصاد سياسى و نفتى نقشى تعيينكثنيده

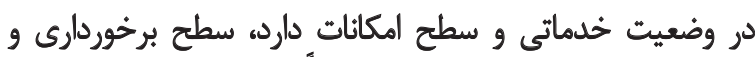

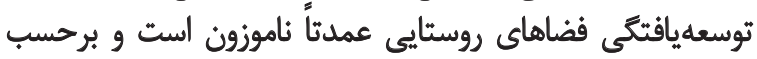

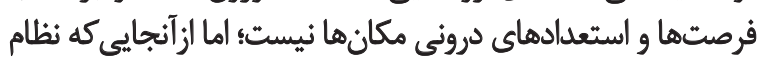

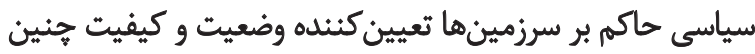

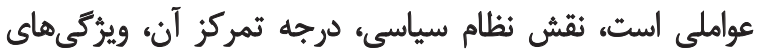

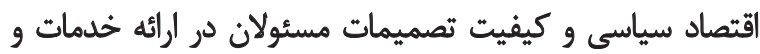

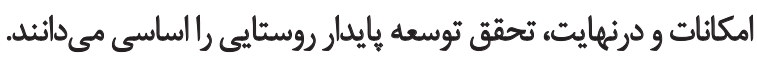
نقش واقعى دولت در توسعهيافتّىى روستايي را عمدناً ميثتوان

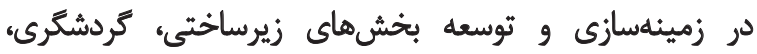

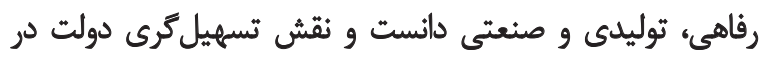

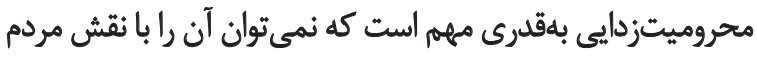

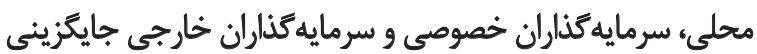

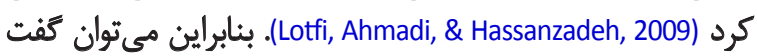

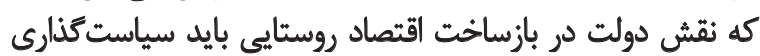

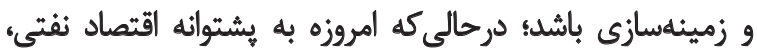

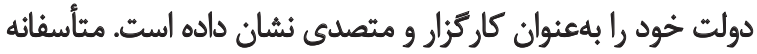

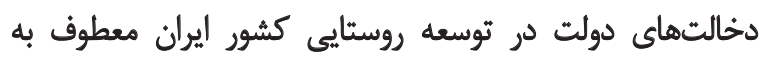

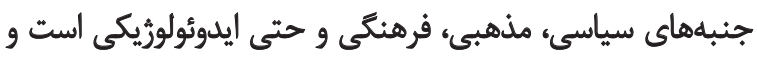
كمتر به جنبه هاى اقتصادى و اجتماعى توجه دارد (Lotfiet al., 2009).

در كشورهايى با نظام سياسى بسيط و اقتصاد نفتى، دو عامل

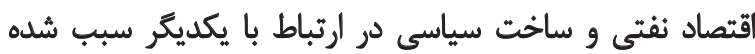

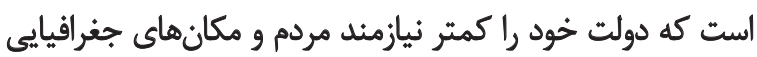

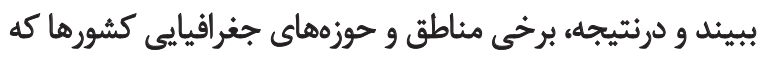

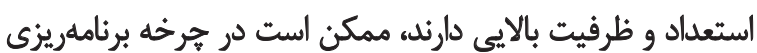
و مديريت واقع نشوند (Gwartney, Holcombe, \& Lawson, 1998).

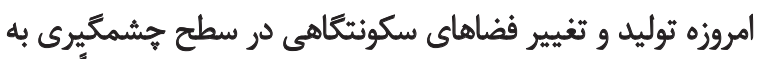

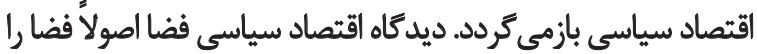

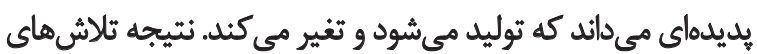

$$
\text { روسثايى راتشريح كرد. }
$$

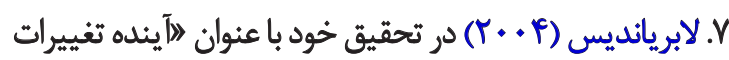

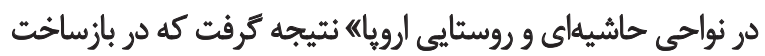

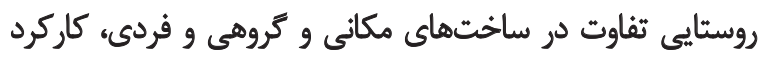

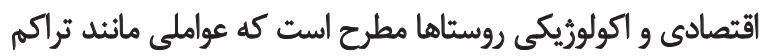

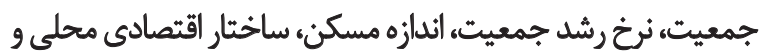
جشمانداز طبيعى رادربرمى رئيرد.

$$
\text { مبانى نظّىى }
$$

فرايندهاي توسعه اقتصادى و اجتماعى و سياسى در بسيارى از

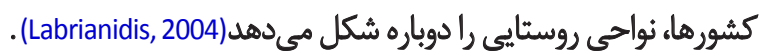

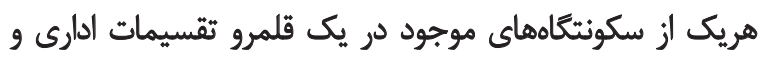

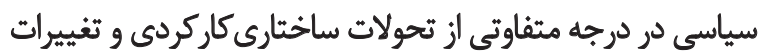

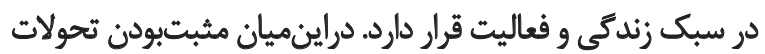

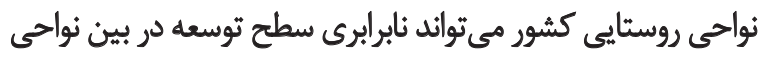

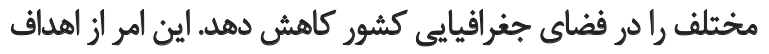

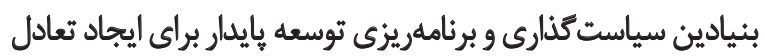

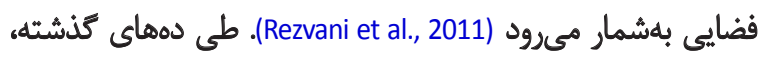

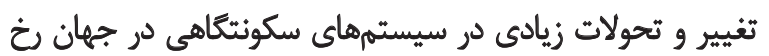

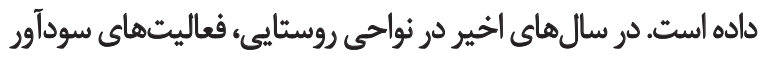

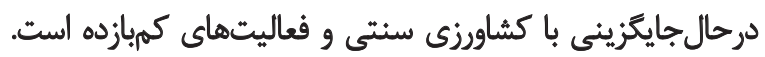

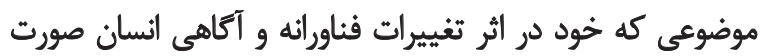

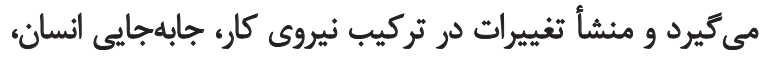

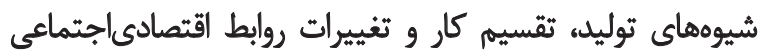

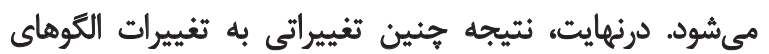

$$
\text { مكانىفضايى ميىانجامد. }
$$

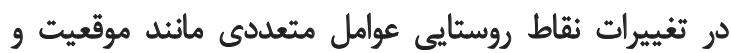

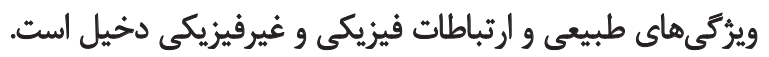

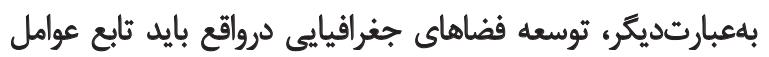

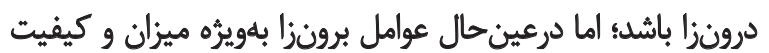

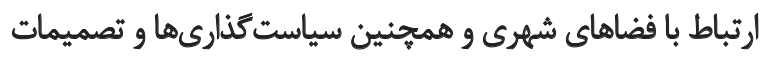

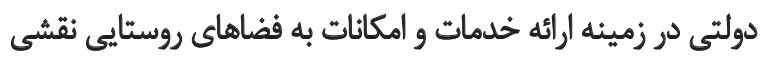

$$
\text { بسيار تعيين كنئده دارد. }
$$

دربارهنقش ارتباط فضاهاي سكونتًاهي با يكديكر بر روند تغييرات،

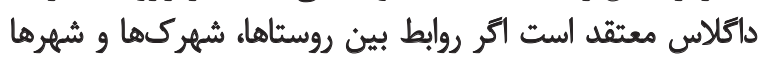

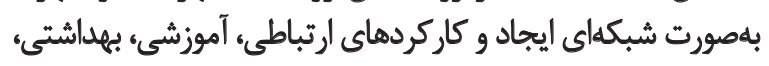

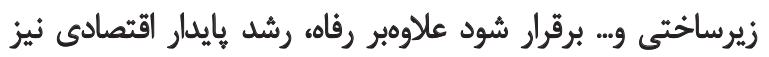

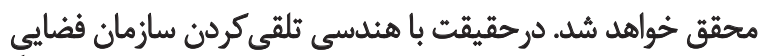

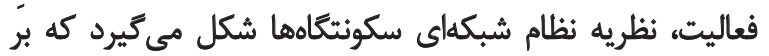

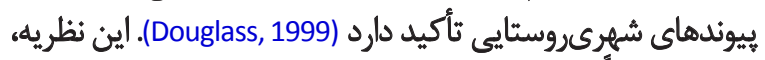

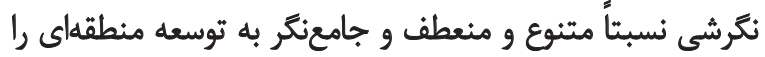

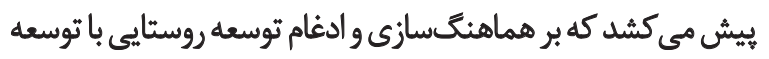




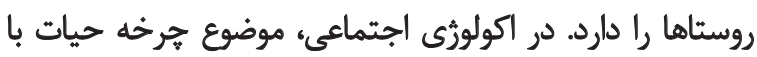

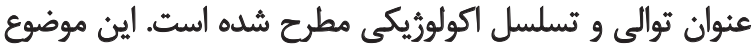

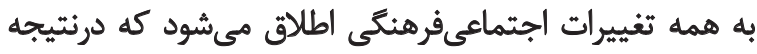

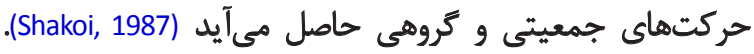

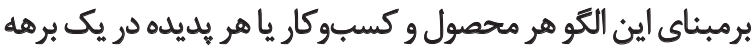

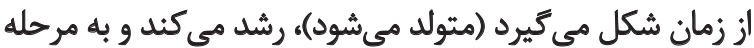

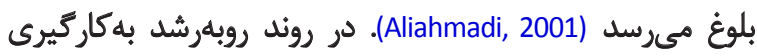

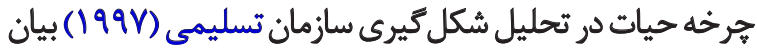

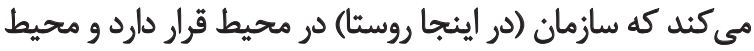

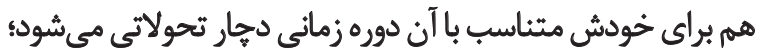

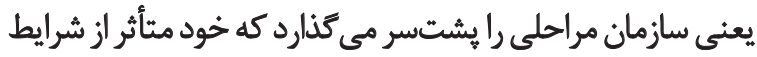

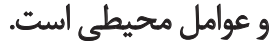

توسعه هايدار نيز ازجمله رويكردهاى نوين در استمرار يايدار روابط

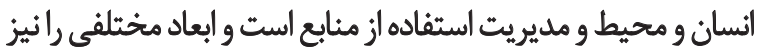

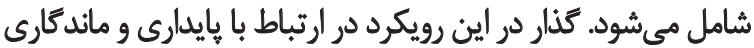

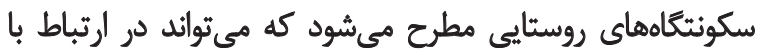

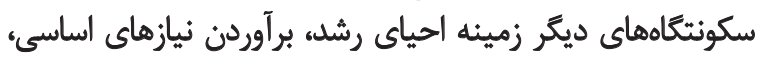

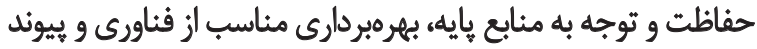

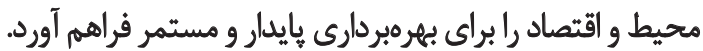
معيارها و شاخص هاي سنجش ميزان تغييرات در نواجي روستايي

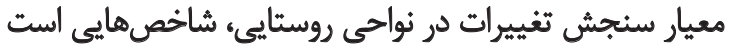

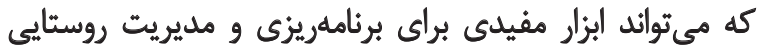

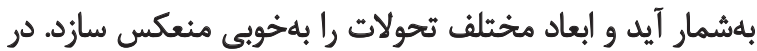

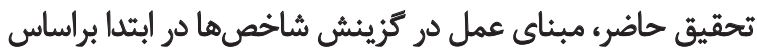

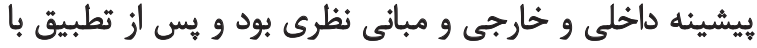

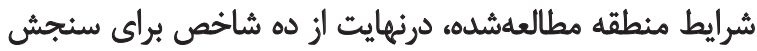

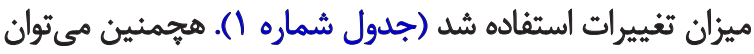

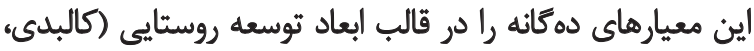

اقتصادى، اجتماعى، و محيطى) خلاصه كرد (تصوير شماره ()).

$$
\text { منطقه بروسى شده }
$$

مركز دهستان دلفارد روستاى رضىىباد از بخش ساردوييه در
صاحبنظران براى كشف سازوكارهاى حاكم بر توليد و بازساخت

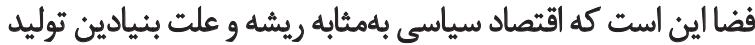

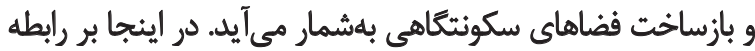

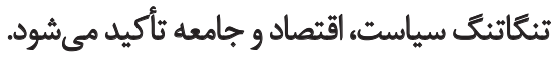

ديويد هاروى در ارتباط بين بازساخت فضا و فرايندهاى

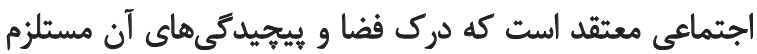

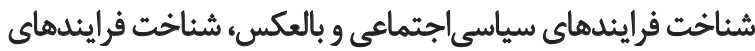

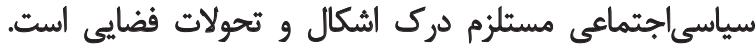

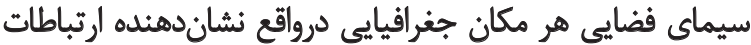
اجتماعى و سياسى حاكم بر آن است (Alsayyad, 1993).

جنين برداشتى الكّى توسعه را فرايندى از پيايين به بالا مى داند

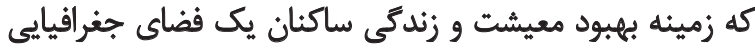

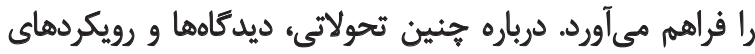

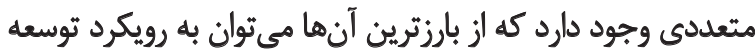

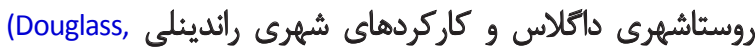

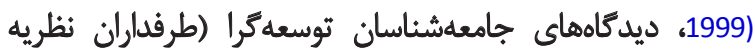

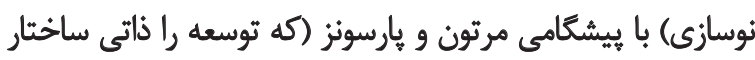

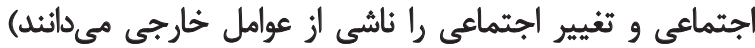

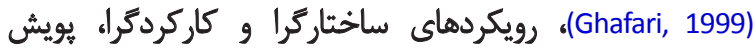

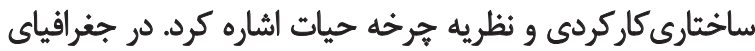

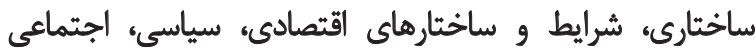

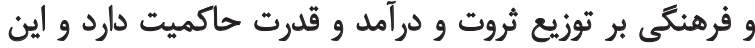

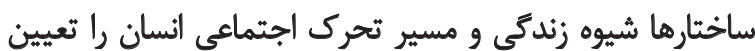

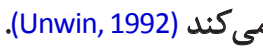

فرض اساسى نظريه يويش ساختارى كاركردى بر اين واقعيت

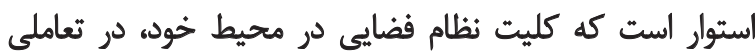

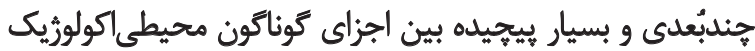

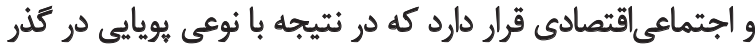

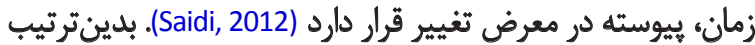

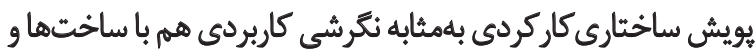

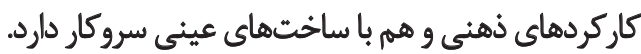
نظريه "جرخه حياته نيز قابليت تبيين تحولات رخداده در

جدول اه ابعاد تغييرات در نواحى روستايي.

\begin{tabular}{|c|c|c|c|}
\hline تغييرات كردشكرى & & تغييرات مسكن & \\
\hline تغييرات الكوى محصولات كشاورزى تغييرات بخش تجارت و بازركانى & تغييرات اقتصادى & 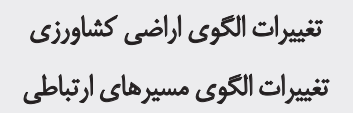 & تغييرات كالبدى \\
\hline تغييرات معيشتى & & تغييرات نوع كاربرى زمين & \\
\hline تغييرات اجتماعى از نظر ساختار سنى اجتماعي ار نظر نرخ الثقاط & تغييرات اجتماعي & 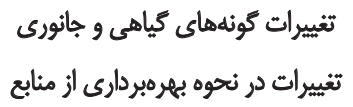 & تغييرات محيطي \\
\hline
\end{tabular}




\section{بررسى روند ثغيير و تحولات روستاهاى دهستان دلفارد}
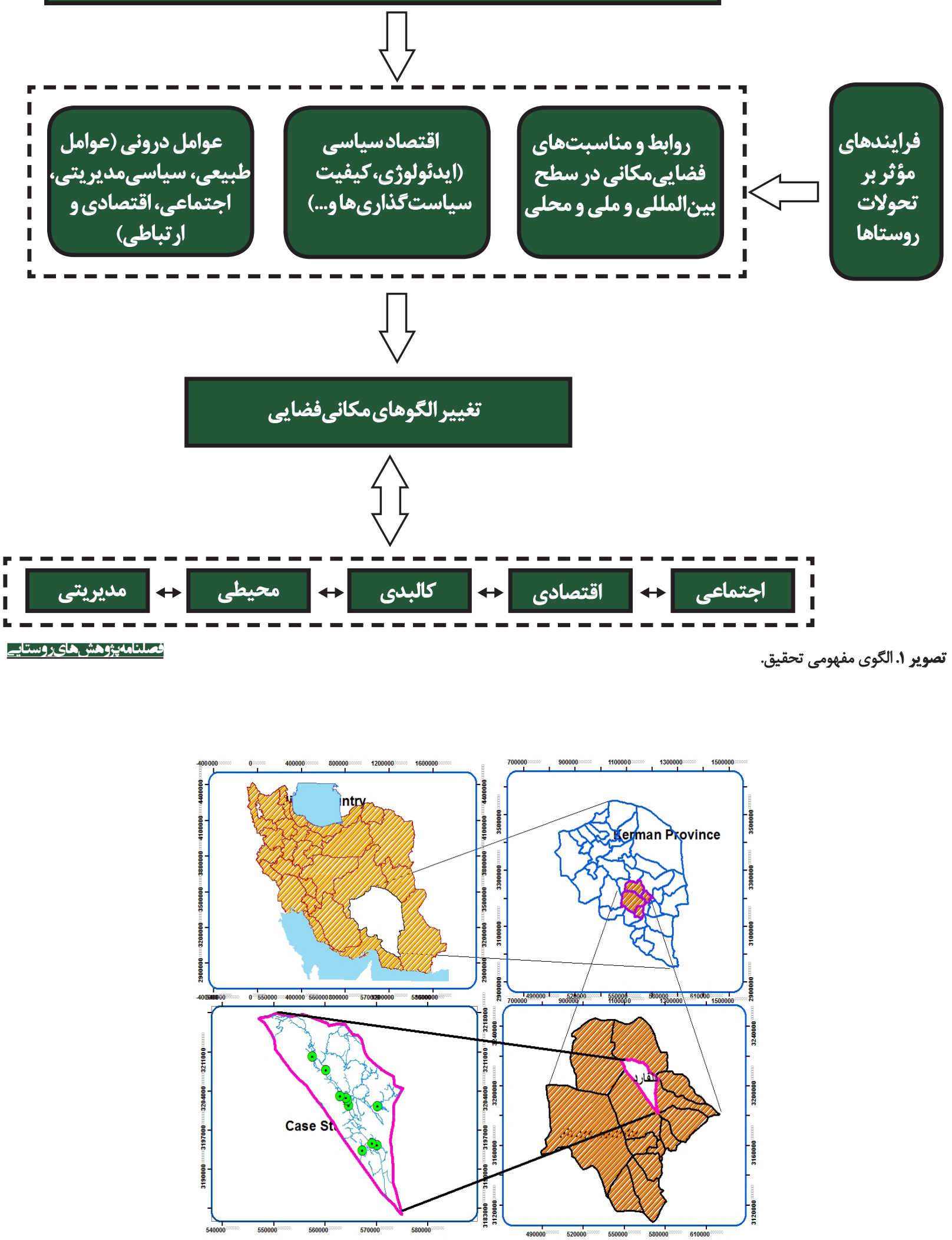

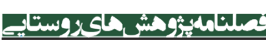

$$
\text { تصوير T. موقعيت دهستان دلفارد در كشور ايرانء استان كرمان و شهرستان جيرقت. }
$$


كه در آن سهم برابرى از (WSM) و الكّوى توليد وزنى براى ارزيابى كزئنها داده شود (Saparauskas, Zavadskas, \& Turskis, 2011)

$$
\begin{aligned}
& Q_{i}=0.5 Q_{i}^{(1)}+0.5 Q_{i}^{(2)} \\
& Q_{i}=\lambda \sum_{j=1}^{n} \bar{x}_{i j} w_{j}+(1-\lambda) \prod_{j=1}^{n}\left(\bar{x}_{i j}\right)^{w_{j}} \quad, \quad \lambda=0, \ldots 1 \\
& \text { مقادير بهينه لم مى تواند با كسترش تابع زير محاسبه شود: } \\
& \lambda=\frac{\sigma^{2}\left(\mathrm{Q}_{i}^{(2)}\right)}{\sigma^{2}\left(\mathrm{Q}_{i}^{(1)}\right)+\sigma^{2}\left(\mathrm{Q}_{i}^{(2)}\right)}
\end{aligned}
$$

واريائسهاى

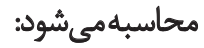

$$
\begin{array}{r}
\sigma^{2}\left(\mathrm{Q}_{i}^{(1)}\right)=\sum_{j=1}^{n} \bar{x}_{i j} w_{j}{ }^{2} \sigma^{2}\left(\overline{\mathrm{x}}_{i j}\right) \\
\sigma^{2}\left(Q_{i}^{(2)}\right)=\sum_{j=1}^{n}\left[\frac{\prod_{j=1}^{n}\left(\bar{x}_{i j}\right)^{w_{j}} \times w_{i j}}{\left(\bar{x}_{i j}\right)^{w_{j}}\left(\bar{x}_{i j}\right)^{\left(1-w_{j}\right)}}\right]^{2} \sigma^{2}\left(x_{i j}\right)
\end{array}
$$

برآورد واريانس مقادير معيارهاى استانداردشده اوليه از طريق فرمولى محاسبه مىشود كه درادامه مى آيد:

$$
\sigma^{2}\left(\bar{x}_{i j}\right)=\left(0.05 \bar{x}_{i j}\right)^{2}
$$

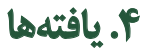

درراستاى ياسخ به سؤال تحقيق حاضر (روند تغيير و تحولات

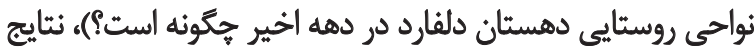

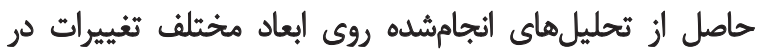

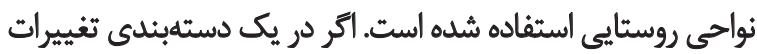

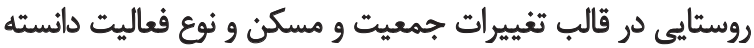

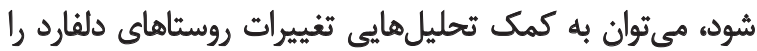

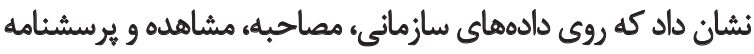

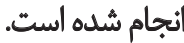
سنجش تحولات روستاها براساس يافتههاى حاصل از آمار سازمانى

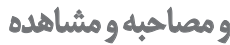

در ابتدا نتايج حاصل از بررسى آمار سازمانى و مصاحبه با مسئولان

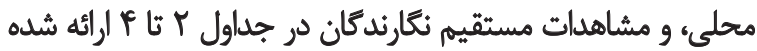

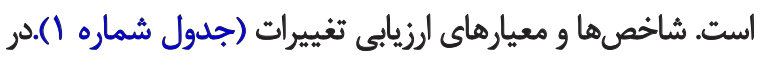
سه بُعد تغييرات جمعيتى و سكونتى و فعاليتى قرار دارد. دادههاى تهاري
ككيلومترى شمالغربيى شهرستان جيرفت است. اين دهستان

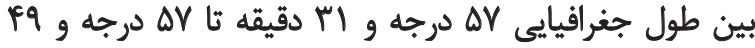

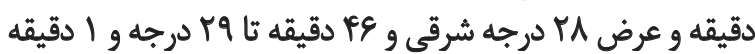

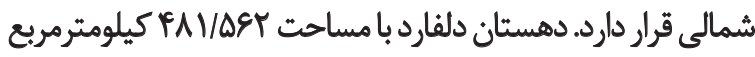

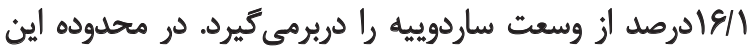

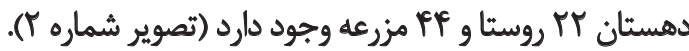

$$
\text { "ا. روش شناسى تحقيق }
$$

نوع تحقيق حاضر توصيفى تحليلى بود و در آن براى كردآئورى و

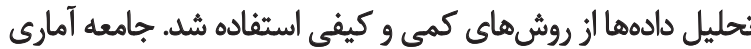

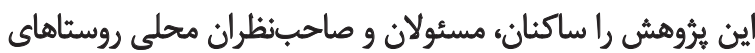

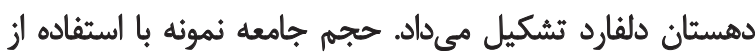

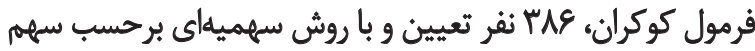
جمعيتى بين روستاهاى ده كانه توزيع شد وردان

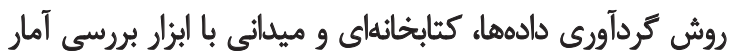

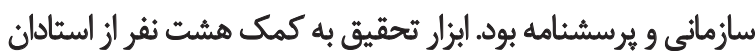

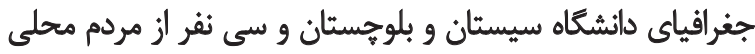

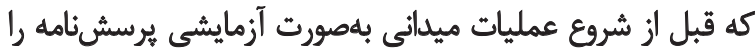

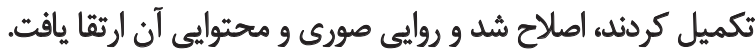

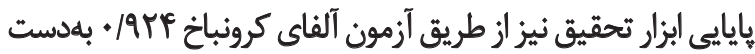

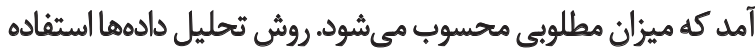

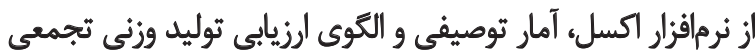
بود. (WASPAS)

يكى از متغيرهايى كه ميثواند در انتخاب الثوى تصميمثيرى

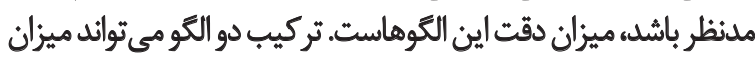

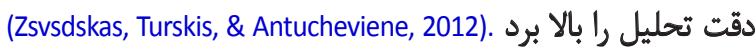

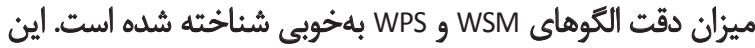

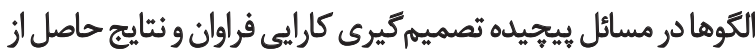

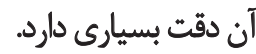
درادامه مراحل الكَو ارزيابى توليد وزنى تجمعى مى آيد:

$$
Q_{I}^{(1)}=\sum_{j=1}^{n} \bar{x}_{i j} \times w_{j}
$$

براساس الكوى توليد وزنى (WPM)' اهميت نسبى كزينه أ ام توام بهعنوان ${ }^{2}$ نشان داده مىشود كه به صورت ثابع زير تعريف مي شُّود (Bridgman, 1922):

$$
Q_{i}^{(2)}=\max \prod_{j=1}^{n}\left(\bar{x}_{i j}\right)^{w_{j}}
$$

سعى شده معيارى تركيبى براى تعيين اولويت هر كزينه بهكار رود 


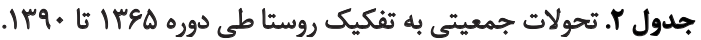

\begin{tabular}{|c|c|c|c|c|c|c|c|c|}
\hline \multicolumn{2}{|c|}{ سرشمارى • " } & \multicolumn{2}{|c|}{ سرشمارى IFAD } & \multicolumn{2}{|c|}{ IrVD سرشمارى } & \multicolumn{2}{|c|}{ سرشمارى ه8rا } & \multirow{2}{*}{ ثام روستا } \\
\hline جمعيت & خاتوار & جمعيت & خاثوار & جمعيت & خانوار & جمعيت & خانوار & \\
\hline re. & ᄉ. & $\wedge$ & $r$ & 1. & $p$ & 1. & r & بجكىى \\
\hline roY & 91 & 11 & $r$ & 8 & 1 & 8 & f & بنستان \\
\hline$r \Delta \xi$ & $q$ & $9 \cdot 0$ & 1.0 & f.. & 88 & MM & r & دهنه زورى \\
\hline req & 1. & Af & r & $1 . r$ & $r_{+}$ & $19 V$ & 8) & انجير بازوييه \\
\hline ITA & ו & Ire & rr & 190 & ני & $14 q$ & $M$ & قلعه \\
\hline rq. & AT & 118 & r. & ז & זr & سه & ir & رزشيرين \\
\hline rqv & זם & DA & rT & MIF & ra & $\Delta$. & r & جكاه \\
\hline $9 \cdot 1$ & $1 F q$ & red & Pl & IrA & r & $r \cdot$ & 19 & باغ علىشير \\
\hline rov & $w$ & $9 \Delta$ & $r$ & 111 & ro & rir & $\Delta F$ & 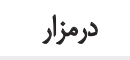 \\
\hline VAq & 191 & rqv & $n^{e}$ & $r+q$ & ro & r & 19 & دائر \\
\hline$r v \cdot A$ & $q$. & MAT & req & Irva & $r r^{e}$ & $94 \lambda$ & MrF & مجموع \\
\hline
\end{tabular}

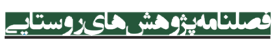

نشان مى دهد كه التوى مسكن در روستاهاى دلفارددرحال تغيير

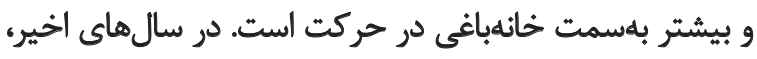

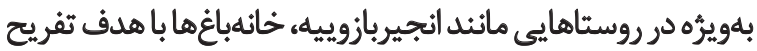
و كذران اوقات فراغت در حال افزايش است.

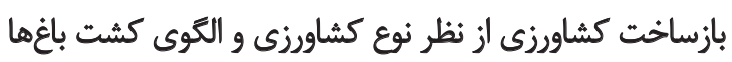

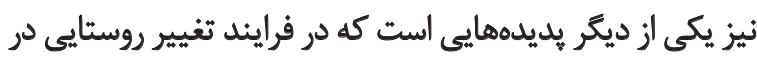

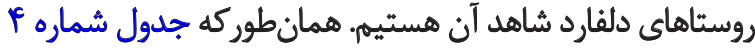
نشان مى دهد، نرخ تغييرات بسيار خشمخير است. ازآنجايى كه مسيرهاى ارتباطى در روستاهاى دلفارد توسعلهيافته

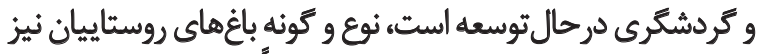

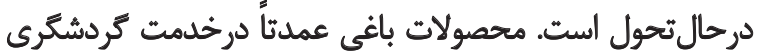

لازم براى تحليل ميزان تغييرات روستاهاى دلفارد در اين سه بُعد

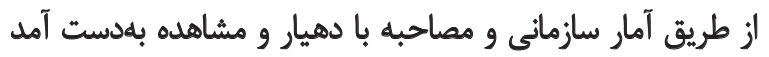

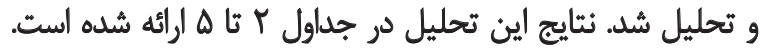

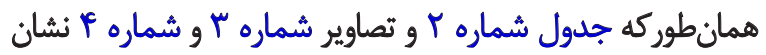

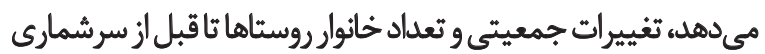

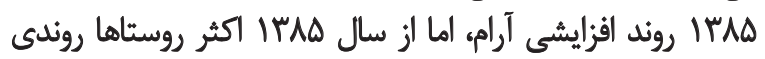
افزايشى سريعى داشته است. براساس جدول شماره ب كه ميزان تغييرات روستاها را الز نظر

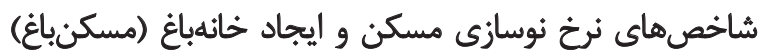

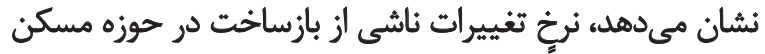

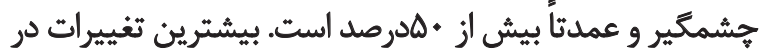

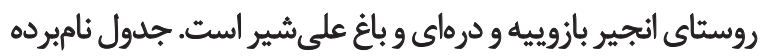

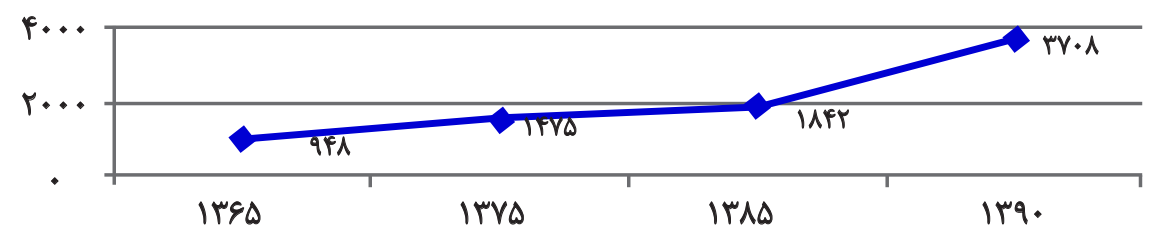

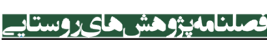

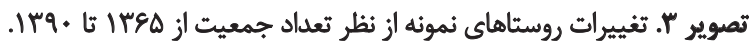

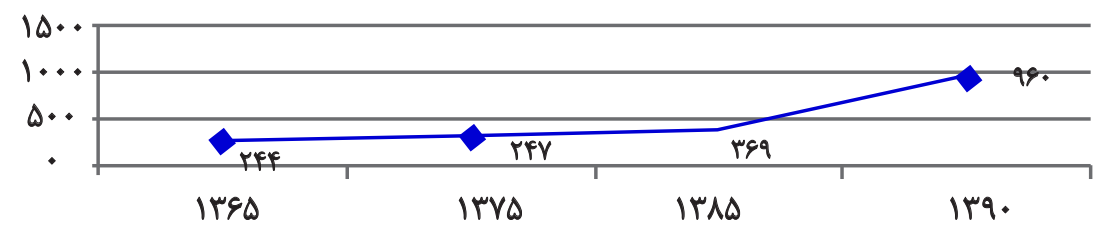


جدول ץ. ئرخ تغييرات مسكن روستاهاى نمونه در ده سال اخير.

\begin{tabular}{|c|c|c|c|c|c|}
\hline سمانم مسكنباغ (خاغ & تعداد مسكن باغ ساخته شده در & سهم مسكن نوساز در & تعداد مسكن بناشده در & كل مسكن & روستا \\
\hline $84 / 1$ & $\Delta$. & $\Lambda \cdot / 1$ & \& & va & درهزار \\
\hline$V \pi / 9$ & gr & AF $/ V$ & $n$ & AS & رزشيرين \\
\hline$V D /$. & 10. & 91 & MAT & r.. & درهاى \\
\hline$r \cdot / q$ & $r *$ & $r I / r$ & f. & qv & جكاه \\
\hline$P \Delta / V$ & A. & $\Lambda \otimes / N$ & $1 \Delta$. & IVD & باغ علىشير \\
\hline$V+1$ & v. & Vq/. & vq & $1 .$. & دهثه زورى \\
\hline AF/ $/ V$ & $r$ & $94 / 1$ & A. & AS & |ثجير بازوييه \\
\hline$V / r$ & re & $\Lambda \pi / N$ & $r$ & p & قلعه \\
\hline$V / \Delta$ & $\Delta$. & $V a / r$ & $\Delta \Delta$ & $9 q$ & بنستان \\
\hline$V / T^{e}$ & gr & $1 \cdot / \Delta$ & v. & AV & بجكSي \\
\hline
\end{tabular}

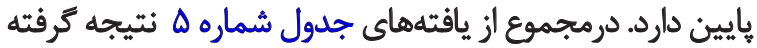

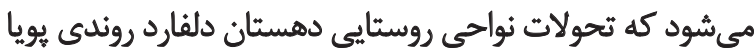

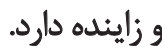

نمودهاى تغييرات ناشى از بازساخت در روستاهاى دلفارد جدول شماره \& بهتفصيل نمودهاى تغييرات ناشي از بازساخت

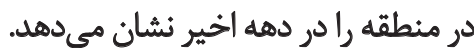

نتايج حاصل از الكوى ارزيابى توليد وزنى تجمعى براي

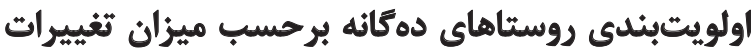

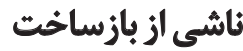

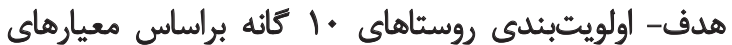

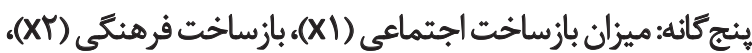

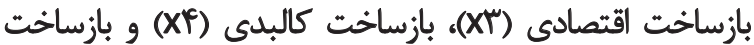

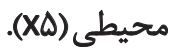

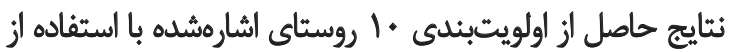

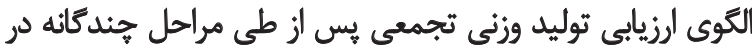

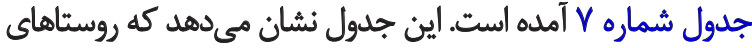

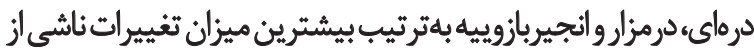

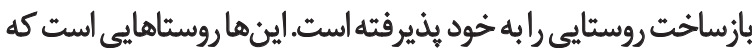

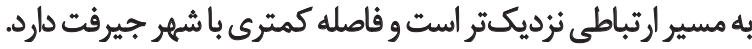

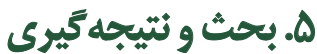

هدف تحقيق حاضر تحليل روند تغيير و تحولات نواحى

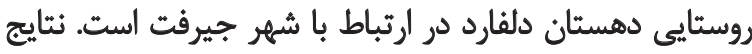

قرار كرفته و بازار هلهاي محلى در ده سال اخير در حاشيه جاده

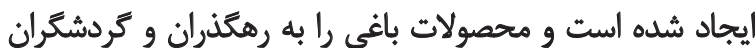

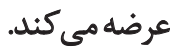

سنججش تحولات روستاهاى مطالعهشده براساس ياقتثهاني

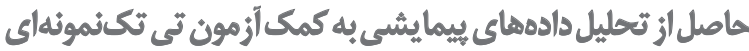
ميزان تغييرات روستاهاي بررسيشده از نظر كويههاي

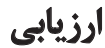

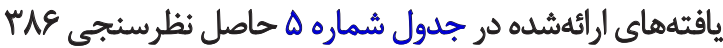

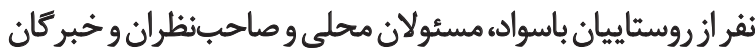

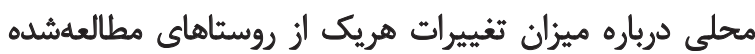

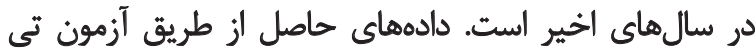

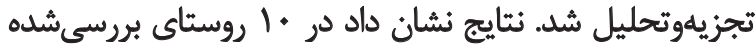

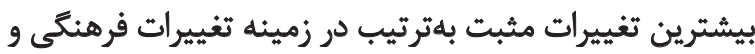

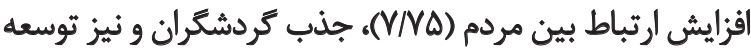

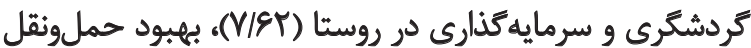

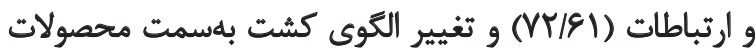

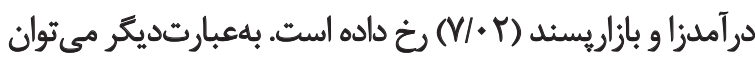

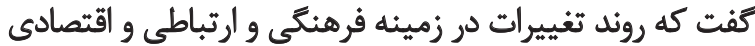

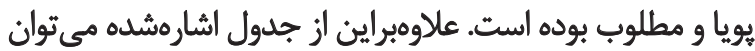

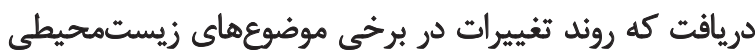

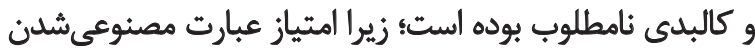

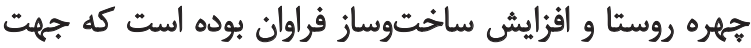

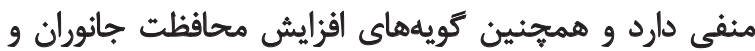
كياهان بر اثر افزايش آكاهى و همكاري همائ مردم و مسئولان امتياز 
جدول F. نرخ تغييرات زراعت به باغدارى و ثرخ تغييرات الكوى كشت روستاهاي نمونه در ده سال اخير.

\begin{tabular}{|c|c|c|c|c|c|c|}
\hline 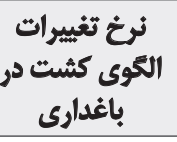 & تعداد باغ هايي كه الكّوى & كل باغات & زراعت به باغدارى تغييرات & 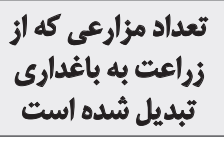 & كل مزارع & روستا \\
\hline$g q / F$ & $m$ & $\mathrm{Fq}$ & $\Delta T / q$ & 18 & AV & درمزار \\
\hline$E q / V$ & r & ve & $p q / 8$ & $8 \lambda$ & Irr & رزشيرين \\
\hline$V \Delta / V$ & KA & rv & $\Delta) / \lambda$ & rq & $\Delta \varepsilon$ & درماي \\
\hline pf & $\mathbb{W}$ & 사 & $8 / /{ }^{\prime}$ & $n$ & 119 & جكاه \\
\hline$r E / F$ & H & $M$ & $9 . / 1$ & 19 & $u$ & باغ على شير \\
\hline $91 /$. & G & $\Delta q$ & $1+18$ & $\Delta f$ & gr & دهئه زورى \\
\hline$F V /$ & 19 & 1.5 & $\Lambda r / q$ & 99 & 111 & انجير بازوييه \\
\hline$\Delta Y / Q$ & re & \&A & $A I /{ }^{\prime \prime}$ & 81 & vo & قلعه \\
\hline PNE & IN & $\mathrm{rV}$ & $\Delta \cdot N$ & $m$ & ev & بُستان \\
\hline rNa & $v$ & $M$ & $r+/ \Delta$ & 9 & rf & بيجكى \\
\hline
\end{tabular}

بازٔساخت نوين كالبدى روسئاها، بازٔساخت دامدارى و كشاورزى،

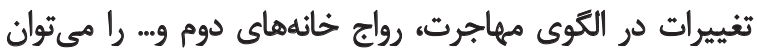
نمودهاى تغييرات بازساختى در منطقه دلفارد دانست

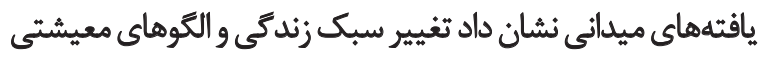

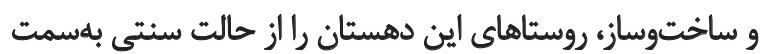

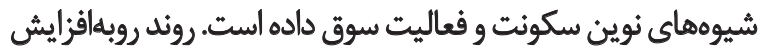

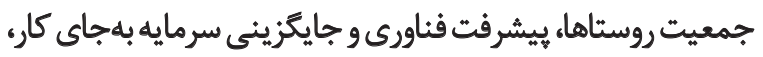

جدول ه. سنجش ميزان تغييرات در ابعاد مختلف زندكى روستاييان در دهستان دلفارد با استفاده از آزمون تى تكنمونهاى.

\begin{tabular}{|c|c|c|c|}
\hline اختلاف باحد متوسط (ه) & امتياز & كويه & $\overline{3}$ \\
\hline V/Fes.. & elese. & افزايش أكاهى و اطلاعات مردم روستاها در نثيجه اسثفاده از امكاثات ارتباطى در سال هاي اخير & \\
\hline $1 / \Delta 9 \ldots$ & $8 / \Delta 9 .$. & تضعيف تبعيضهاى جنسيتى و افكار منفى درباره برابرى زن و هرد در روستاها & \\
\hline$\cdot / \mu+$. & $\Delta / / r+\cdots$ & افزايش دسترسى به خدمات و امكانات زئدكى در روسثاها در سال هاى اخير & \\
\hline $1 / r v+$. & $e / \pi \vee$. & افزايش رغبت ماندن در روستاها در سالهاى اخير بهعلت بهبود وضعيت تغذيه و بهداشت & \\
\hline $1 / r \ldots$ & $s / r \ldots$ & اقزايش تعلق و كرايش بهسوى روستاها در سالهاى اخير & $\frac{s}{4}$ \\
\hline$V / \Delta \% \ldots$ & \&/ه९.. & افزرايش ماندكارى در روستا بهسبب بهبود امثيث و اعتماد به مسئولان در سال هاي احير & \\
\hline$r / 91 \ldots$ & $v / 91 \ldots$ & جذب مردم به روستاو ماثدكارى أثان در أنجا بهدليل بهبود حملونثل و ارتباطات در سالهاى اخير & \\
\hline$\cdot / \Lambda+\cdots$ & $\Delta / 1+\cdots$ & بهيبود زمينه ايجاد شغل و كار و فعاليت در روستا در سال هاى اخير & \\
\hline $1 / F V+$. & s/FV.. & افزايش رضايت ساكنان روستايى از خدماتى ماندلد آبه برق، راه، انرثى و... در سال هاى اخير & \\
\hline
\end{tabular}




\begin{tabular}{|c|c|c|c|}
\hline 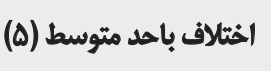 & امثياز & كويه & $\overline{3}$ \\
\hline $1 / \cdots+$ & $91 \ldots$ & جذب مردم به روستاو ماندكارى آنان در أنجا بلهخاطر احياى سنتها و باورهاى موجود روستا در سال هاى اخير & \\
\hline $1 / M \ldots$ & s/M.. & بهبود نكرشها و رفتار روستاييان در زمينه ارثباط و زندكى با ديكر مردم در سال هاى اخير & 2 \\
\hline T/NA ... & $V / V \Delta .$. & توسعه و ييشرفت روستا بهسبب بهبود تغييرات فرهنكى و افزايش ارتباط بين مردم در سال هاي احير & \\
\hline $1 / 94 \ldots$ & s/af.+ & بهبود سبك زندكى مردم و سبك فعاليت مردم در سال هاى اخير & \\
\hline$. / M+. .+$ & $\Delta / T H \cdot$. & افزايش ميزان رضايت روستاييان از فعاليتهاي اقتصادى روستاها در سالهاي احير & \\
\hline$\cdot /$ Ar... & $\Delta / A Y+\infty$ & افزايش راههاى كسب و بهيبود درآمد روستاييان در سال هاى اخير & \\
\hline $1 / 1+\ldots$ & g/A... & ايجاد شغل هاي جديل كردشكرى، صنعتى، بازار و... در روستاها در سال هاى اخير & \\
\hline $1 / \Delta q \ldots$ & $8 / \Delta q_{0}$ & تغيير معيشت اهالى از كشاورزى به كارهاى خلدماتى روستاها دربرابر روسثاهاى ديكر & \\
\hline$r / \cdot r+.$. & $V / \cdot r+$. & تغيير الكوى كشت بهسمت محصولات درآمدزا و بازاريسند در روستاها در سالهاى اخير & 的 \\
\hline$V / / \gamma+\infty$ & $9 / N \gamma^{\prime}$. & 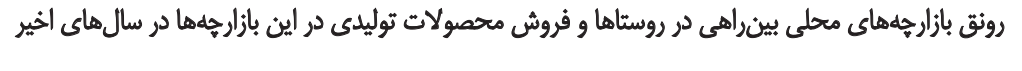 & \\
\hline $1 / r v \cdots$ & $8 / m V$ & افزايش دلكرمى و تمايل مردم به زندىى در روستاها بهعلت سرمايهكذارىهاي دولثي & \\
\hline $1 / \Delta \Delta \cdots$ & $\varepsilon / \Delta \Delta \cdots$ & بهيود شرايط مالى، اقتصادى و معيشتى روسثاها در سالهاي اخير & \\
\hline$M+\cdots$ & $s / \cdots+\cdots$ & بهبود ارتباطات بين مكانى و سرمايهكذارى بخش در سال هاى اخير & \\
\hline$r / T \Delta \ldots$ & NTA.. & افزايش ساختتوسازهاى ايمن و مقاوم در روستاها در سال هاى اخير & \\
\hline $1 / \Delta \& \ldots$ & \&/AC.. & افزٔايش ساختوساز براى اهداف تجارى و كردشكرى و كاركاهى در روستاها در سالهاى اخير & \\
\hline$r / \cdot 1 \cdot .+$ & $\mathrm{V} / \cdot \wedge \cdot \cdot$ & افزايش بناي ساختمانهاى زييا و جذاب در روستاها در سالهاي اخير & \\
\hline$r / / f+\cdots$ & NIF+. & افزايش نوسازى و بهسازى ساختمانهاى روستاها در سال هاى اخير & \\
\hline$r /+\%+$. & $N \cdot r+$. & اقزايش بناى ساختمان هاى استاندارد و قانونمند در سال هاى اخير & \\
\hline r/\&A... & $V / \& \Lambda .$. & هصنوعىشن جهره روستاها و افزايش ساختوساز بهدليل افزرايش قيمت زمين در سال هاي اخير & \\
\hline l/ır... & \&/ıн.. & بهبود زيرساختهايى مانند جاده آسفالت، يلها و... و عبورومرور در روستاها در سال هاى اخير & \\
\hline $1 / r \%+\cdots$ & $s / M V+$. & افزايش تأسيسات أموزثىى، بهلاشتى، درمانى و... در روستاها در سال هاى اخير & \\
\hline r/gr... & V/ar.. & جذب كردشَّران و سرمايهكذاران به روستاها بهسبب آبوهواى خوش روستاها & \\
\hline $1 / \Delta q+$. & $8 / 09 .$. & بهيود بهداشت و سلامتى محيط با افزايش همكارى مردم و مسئولان روستاها در سالهاي اخير & \\
\hline$. / M r+. \cdot$ & $\Delta / r+$. & افزايش محافظث از كياهان و كاشت درختان طبيعى با اقزايش أكاهي و همكارى مردم و مسئولان & \\
\hline$-+/ q_{+++}$ & $4 / M T_{+\infty}$ & افزايش محافظت از حيوانات و كمى به تجديد نسل آنها با افزايش أكاهى مردم و اقدامات مسئولان & \\
\hline$\cdot / r+\cdots$ & $\Delta / r+\cdots$ & كاهش ثابودى جانوران و درختان روسثاها در سال هاى اخير بر اثر أكاهى و دلسوزى مردم & \\
\hline
\end{tabular}


جدول و. نمودهاي تغييرات ناشى از بازساخت از نظر معيارهاي دهكائه.

\begin{tabular}{|c|c|c|}
\hline 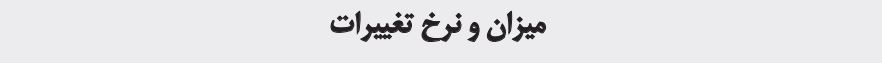 & مؤلفه (توضيح) & توع تثييرات \\
\hline 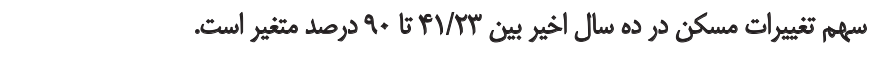 & تعلاد خانه ساختهشده (ثرخ ساخت مسكن) & تغييرات مسكن \\
\hline 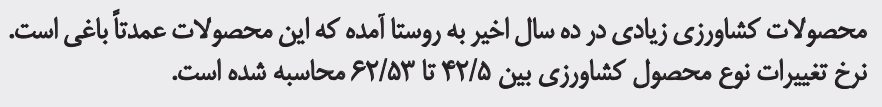 & رواجيير الكوى كشت و ميزان جايكزينى محصدولد ونوع محصولات & كشيير مجصولات \\
\hline 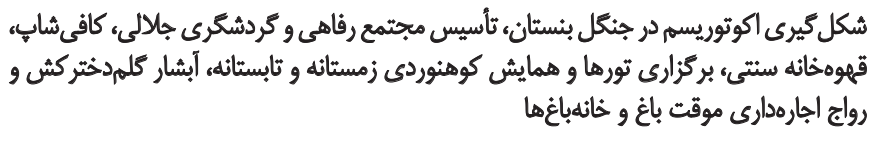 & روساناها و نمودهاى توسعه كردشكرى در & تغييرات كردشكَّى \\
\hline فروشكاه ابزار كشاورزى بلوكنى، احداث سويرماركت، ناثوايى، احداث بازارجههاى محلى بينراهى، & و شيوه عرضه محصول بازل روستاو مغازههاى احداثشده & تجارت و بازركانى تخيرات بخش \\
\hline 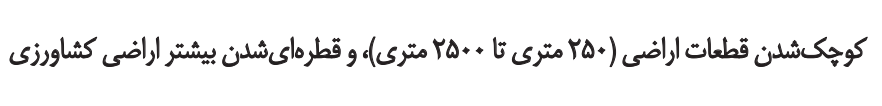 & تردشاد قطعات و أثدازه قطعات زمين و هيزان & بازباخت الكوى ارضى \\
\hline 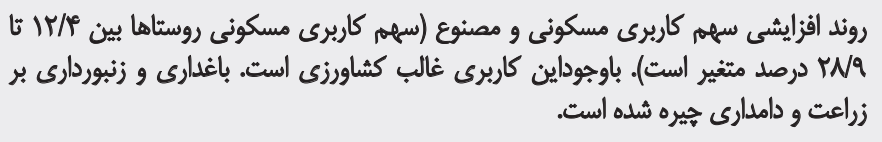 & 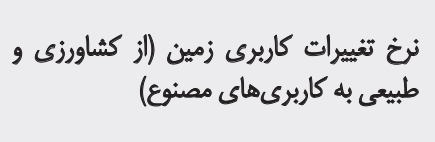 & تغييرات كاربرى \\
\hline حملنيير در نوع جاده ارتباطى (آسفالتشدن مسير ارتباطى شهر به روستاها)، افزايش وسايل & تغيير در نوع مسيرهاى ارتباطى و تغيير در & تغييرات الكوى ارتباطىى \\
\hline 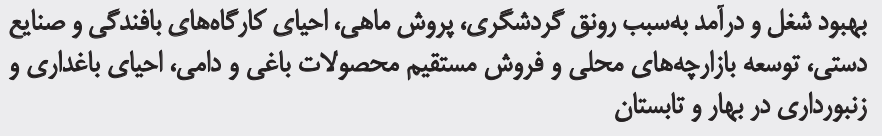 & به مشاغل سنتى مانثد دامدارى و كشاورزى انسبت مشاغل ثوين & بشتى \\
\hline
\end{tabular}

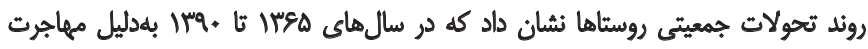

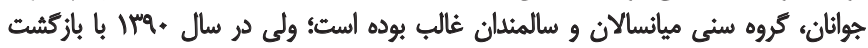

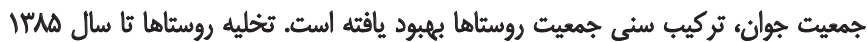

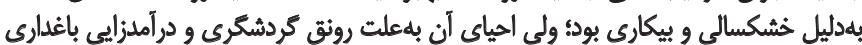

تغييرات اجتماعي از نسبت جوائان ساكن روستا به افراد ميانسال

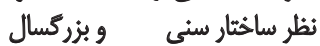

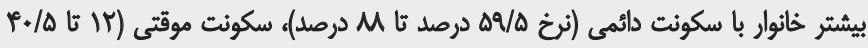

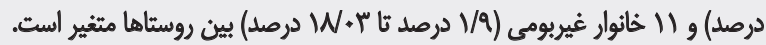

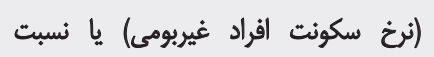
خانوارهاى غيربومى به كل خانوارهاى سراكن

تغييرات اجتماعي ار نظر نرخ الثقاط

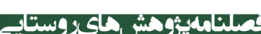

تغييرات ملموس و عينى در زمينه سكونتى و معيشتى و جمعيتى روستاهاى دلفارد ملموس است.

تحولات فضايى مكانى و تحولات اقتصادىاجتماعى، مديريتى

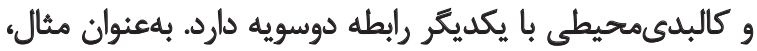

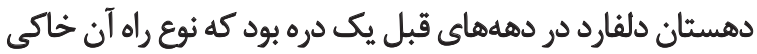

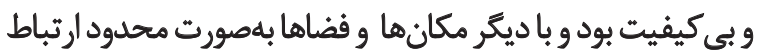

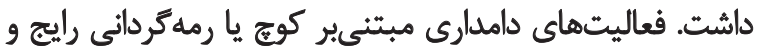

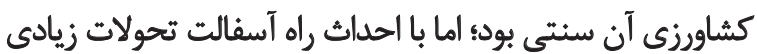

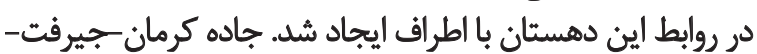

يافتههاي تحقيق حاضر نتايج محققانى مانثل وودز (I (Y)،

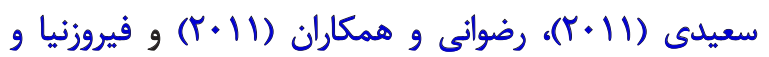

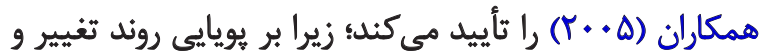

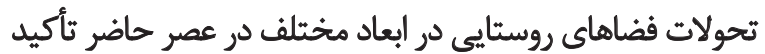

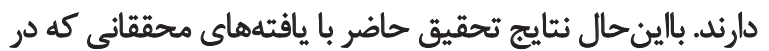

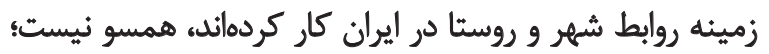

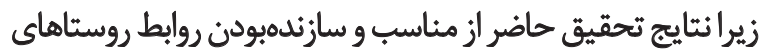

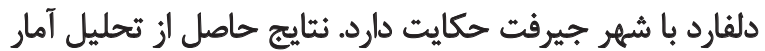

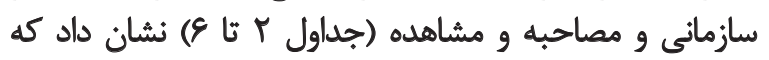




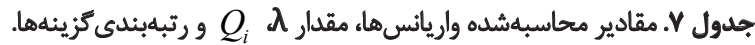

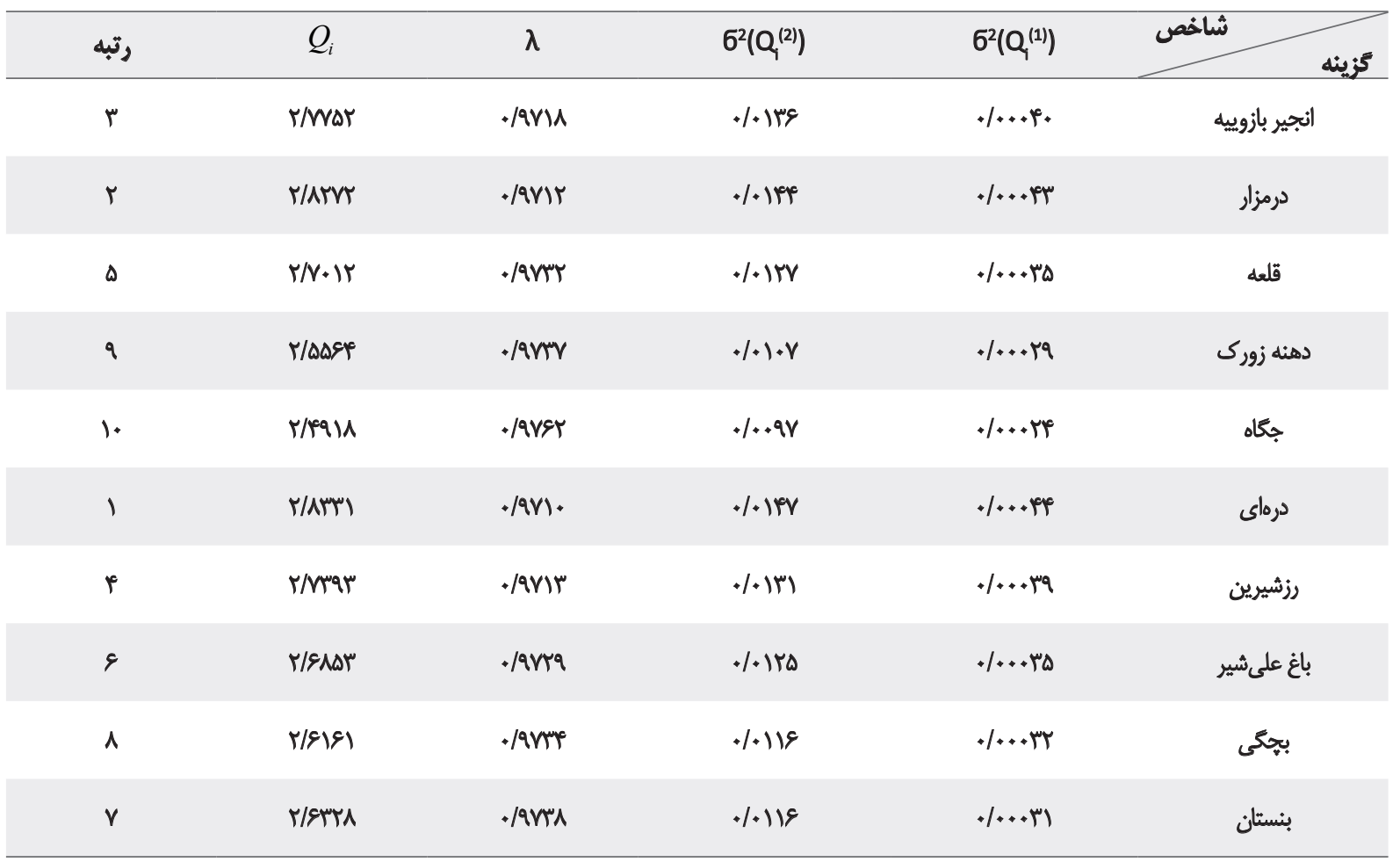

بهمراه نظمم و جذابيت روبهتحول است و ناسازكارى اجتماعى و

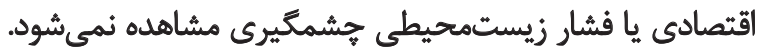

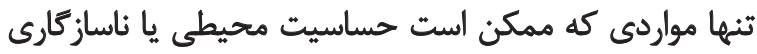

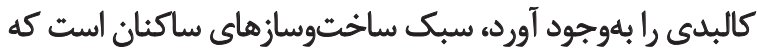

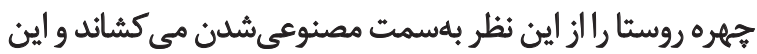

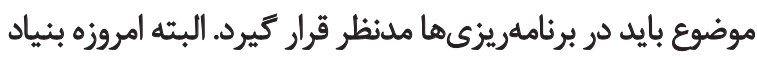

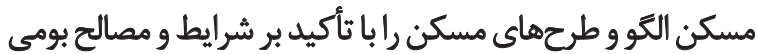
تبهيه كرده و در حال اجراي آنهاست. موني

علاوهبراين از نظر زيستمحيطي نيز در حفاظت از كان بعضي

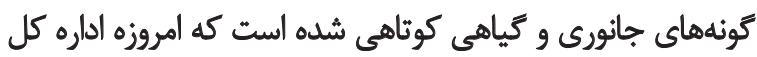

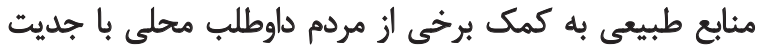

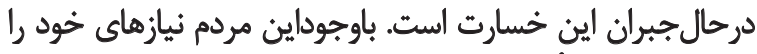

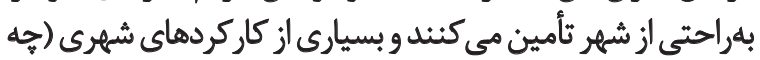

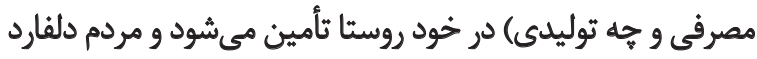

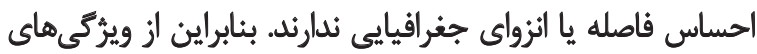

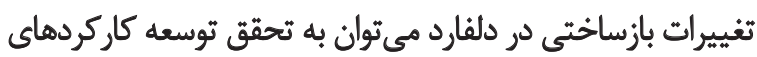

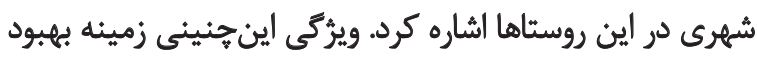

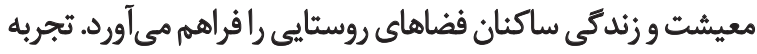

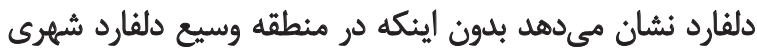

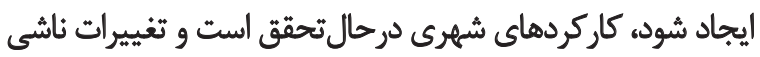

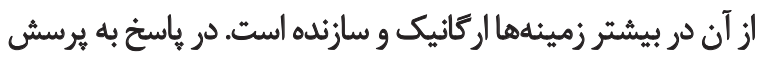
تحقيق ميثوان نتيجه كرفت كه تغيير و تحولات نواحي روستئي
بئدرعباس از وسط آن عبور كرد و حجم روابط با شهر جيرفت

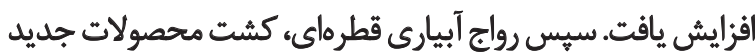
بلويره محصولات باغى و تغيير شيوههاى دامدارى آشكار شد. در دها اخير اندازه و تعداد روستاها بيشتر شده است و اين

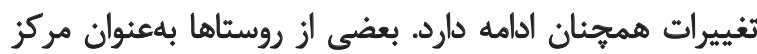

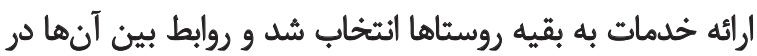

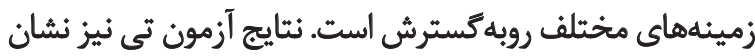

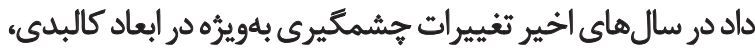

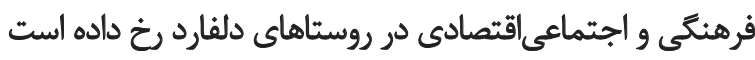

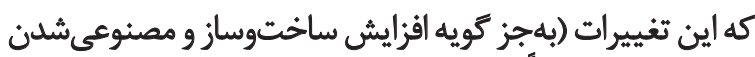

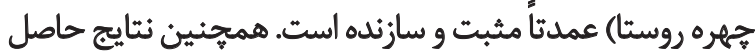

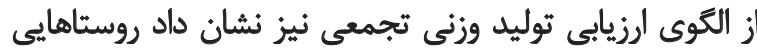

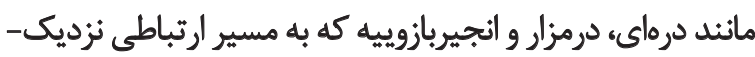

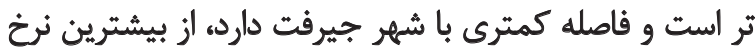

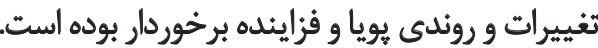

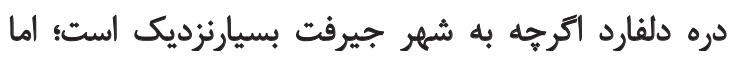

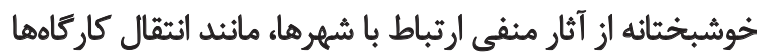

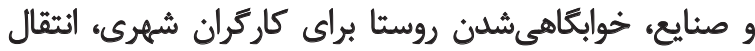

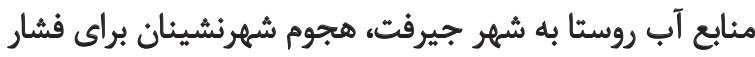

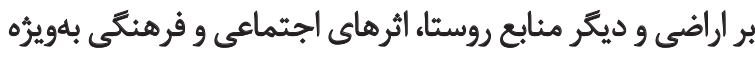

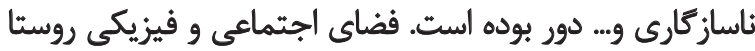




\section{References}

Afrakhteh, H. (1999). [Relations between cities and villages in Iranshahr (Persian)]. Journal of Humanities and Social Sciences of Shiraz University, 16(2), 49-73.

Aliahmadi, A. R. (2001). [A comprehensive approach to strategic management (Persian)]. Tehran: Knowledge Production Publications.

Alizadeh, K., Hejrati, M. H., \& Ahmedabadi, M. (2013). [Examine the relationship between towns and villages (Persian)]. Geographical Landscape in Human Studies, 8(24), 133-45.

Alsayyad, N. (1993). Squatting and culture: a comparative analysis of informal developments in Latin America and the Middle East. Habitat International, 17(1), 33-44.

Bridgman, P. W. (1922). Dimensional analysis. New Haven: Yale University Press.

Cloke, P. (2008). Conceptualizing ruralirty. In P. Cloke, T. Marsden \& P. Mooney (Eds.), Handbook of rural studies (pp. 18-28). London: Sage Publication.

Douglass, M. (1999). Rural urban integration and regional resilience: Strategies for the ruralurban transition in northeast Thailand. Bangkok: NESDB Pub.

Firouznia, Qadiri and tavana, Mohammad Zia (2005). [Explain the process of rural development, using the theory of "life cycle" (Persian)]. Society \& Economy, 13(2), 41-58.

Ghafari, G. (1999). [Social and cultural factors affecting participation as a mechanism for the development of rural villagers Iran, Kashan villages (Persian)] (MA thesis). Tehran: Tehran University.

Gwartney, J., Holcombe, R., \& Lawson, R. (1998). Scope of Government and the Wealth of Nations. Cato Journal, 18(2), 8-12.

Labrianidis, L. (ed.). (2004). The future of Europe's Rural Peripheries: the role of entrepreneurship in responding to employment problems and social marginalisation. Aldershot: Ashgate Publication.

Lotf, H., Ahmadi, A., \& Hassanzadeh, D. (2009). [Essential indicators in plicy-making and planning for rural houses in Iran (Persian)]. landuse planinig quarterly, No 7, 88-89.

Mirzaee Ghaleh, F., Kalantari, Kh., Molaei, M., \& Azmi, E. (2013). [Analyzing the relationship between towns and villages in rural development: Rural suburban Harsin (Persian)]. Housing and Rural Environment, 32(143), 89-91.

Pepper, D. (1984). The Roots of Modern environmentalism. London: Routledge Press.

Rahmani Fazli, A., \& Parishan, M. (2009). [Structural changes in the function of rural areas around city: Kanysoor of Baneh (Persian)] Journal of Applied Research in the Geographical Sciences, 9(7), 101-128.

Rezvani, M. R. (2000). [Analysis of urban-rural relations in rural areas around Tehran (Persian)]. Geographical Research Quarterly, 43, 81-94.

Rezvani, M. R., Sadeqlo, T., \& Sojasi Kedari, H. (2011). [Measurement of Pastoralists level using fuzzy-TOPSIS model (Case study: rural central city of khodabandeh) (Persian)]. Journal of Rural Research, 2(1), 1-31.

shakoi, H. (1987). [New ideas in philosophy of geography (Persian)]. Tehran: Gitashenasi Publications.

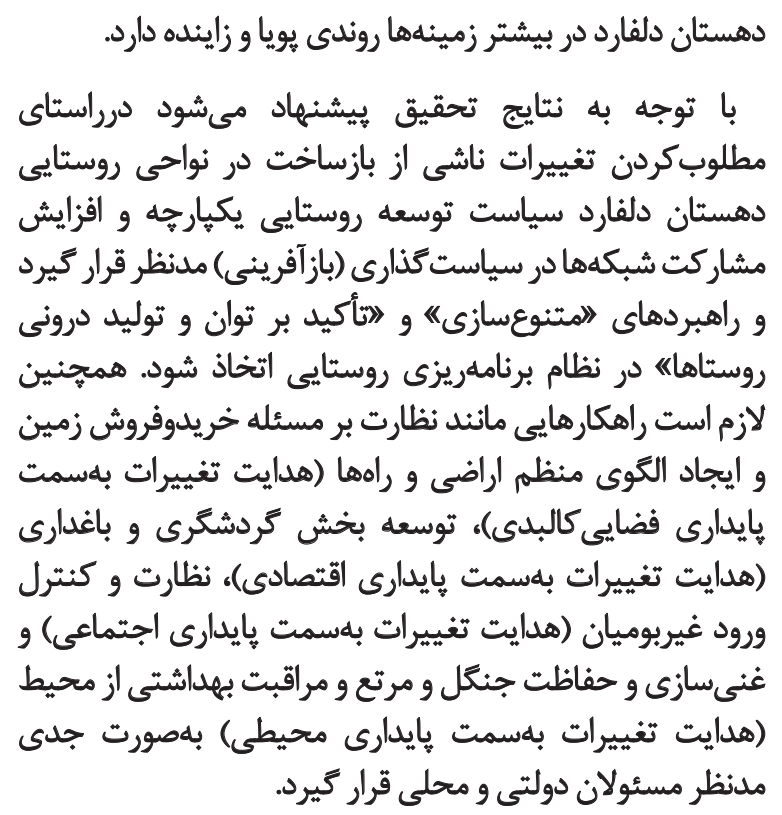


Tacoli, C. (2003). The links between urban and rural development. Environment and Urbanization, 15(1), 3-12.

Saidi, A. (2011). [Structuralfunctual dynamics: sistematic approach in spatial studies (Persian)]. Geography Quarterly, 9(29), 7-16.

Saidi, A. (2012). [Structural dynamics functional: an alternative approach to spatial planning, environment and rural development (Persian)]. Space Economy and Rural Development, 1(1), 1-19.

Saidi, A., \& Ahmadi, M. (2011). [Urbanization and functional-structural transformation in rural houses: the villages surrounding the city of Zanjan (Persian)]. Geography Quarterly, 9(13), 1-20.

Saidi, A., Rahmani Fazli, A., Azizpour, F, \& Mohebbi, A. (2013). [Housing and structural-functional integration: a discussion Nzamvargy rural atmosphere (Persian)]. Geography Quarterly, 11(39), 7-32.

Saparauskas, J., Zavadskas, E. K., \& Turskis, Z. (2011). Selection of Facade's Alternatives of Commercial and Public Buildings Based on Multiple Criteria. International Journal of Strategic Property Management, 15(2), 189-203.

Taslimi, M. S. (1997). [Analize of the decision-making proces (Persian)]. Tehran: Samt Publication.

Unwin, T. (1992). The place of Geography. Harlow: Longman Scientific \& Technical.

Woods, M. (2011). Rural geography (processes, reactions and experiences of rural reform) (M. R. Rezvani \& F. Sameti, Persian Trans.). Tehran: Tehran University Press.

Wirth, L. (1938). Urbanism as Way of Life. American Journal of Physiology, 44(1), 1-2.

Yankson, P. W. (2004). Decentralisation and poverty reduction: the role of district assemblies in Ghana. Paper presented at the NUFU Workshop on Poverty. Legon, Ghana, 6-8 October 2005.

Zavadskas, E. K., Turskis, Z., Antucheviciene, J., \& Zakarevicius, A. (2012). Optimization of weighted aggregated sum product assessment. Elektronika ir Elektrotechnika, 122(6), 3-6. 
